Coverage and Underwriting Aspects of Burglary Insurance by WALKER S. RICHARDSON and RICHARD J. WOLFRUM.

This paper is a discussion of the coverage, rating, and underwriting considerations involved in providing burglary insurance for non-banking commercial enterprises in the United States.

The authors compare the many different policy forms and show that all standard coverages are obtained by mixing location, time and manner of occurrence. The movement toward consolidation of coverages into simpler packages is discussed and further simplification is advocated. The authors point out a number of areas where improvements could be made such as in coverage, territorial assignments, compilation of statistical data and experience rating of individual risks.

The Rating of Crop-Hail Insurance by RichaRD J. ROTH.

The development of rates for the insurance of growing crops against hail requires the scientific blending of insurance statistics with meteorological data. The resulting rating plan is probably the most scientific of any plan used anywhere and deserves study by actuaries interested in the development of more scientific property insurance rate making.

\title{
Seminary Reports.
}

The following subjects are discussed in the Seminar Reports: Automobile Merit Rating, Multiple Peril Policies, Non-Cancellable Accident and Sickness Policies, Guaranteed Renewable Automobile Insurance, Hospital and Surgical Insurance for the Aged and Statistics for Rating and Research.

L. H. Longley-Cook

Zur Beeinflussung des Hagelkornwachstums, by RoLAND List, Journal of Applied Mathematics and Physics, Vol. XIII, Basle and Stuuttgart, I962.

The professional duties of an insurer will not be fulfilled as long as his one purpose is restricted to the evaluation of the underlying risk. In fact, one of the proper functions of the professional insurer consists in studying methods to decrease the relevant risk rate. In life assurance this has been accepted for a long time and motor insurers have also been concerned with this problem. However, as regards hail insurance the literature on actuarial aspects is rather limited and even in the extensive bibliography published in Vol. I, Part II of this Bulletin no paper dealing with the question of how hail damage might be reduced is mentioned. It is therefore of some interest to have regard to other scientific investigations relating to this subject.

R. List, Switzerland's well-known hail expert has recently published an article entitled "The Influence on the Hail Accretion Rate". According to his experience the damage from hail will normally be lowered if the accretion rate of a growing hailstone is decreased and one method of achieving this consists in drying the deposit of such a hailstone. Under such conditions the accretion rate can be slowed down and the method can be further improved if the small cloud particles are partially frozen because in such a 
solid state they will mostly be rejected from the dry surface of the hailstone. However, in order to reduce the growth rate noticeably, calculations show that a high ratio of cloud droplets must be frozen.

\section{Die Schadenstruktur in der Kraftfahr-Haftpflichtversicherung von Personenwagen, by JoHAnnes Mehring, Blätter der deutschen Gesellschaft fïr Versicherungsmathematik, Wurzburg, October 1962.}

In 1962 all price-fixing agreements for rating in motor insurance were cancelled in Germany. Insurance companies were compelled to develop their own statistics and to compile a record of their individual claim experience. The rate making procedure to be applied became of major importance. The notable German expert Dr. Johannes Mehring, has recently published another paper about the significance of the different risk elements in German motor insurance business and the conclusions to be drawn from such information. The main purpose of the paper was to acquaint all readers who are not mathematically trained with the problems involved in this branch. Mathematical formulae have therefore been replaced by graphs. The influence on the claim frequency of horsepower, territory, mileage, age of driver and experience of driver is shown in tables and graphs.

In another section the significance of finding homogeneous classes is outlined. It is shown that a bonus system gives far better results, especially for groups which have been accident-free for several years, than a breakdown by territories. The claim frequency substantially decreased with the growth of the accident-free period but this effect is weakened by the fact that claim costs for an accident increase concurrently.

As an optim um solution the author describes a form of classification rating that offers rate reduction for accident-free driving and penalizes the driver with repeated accidents. Actually a rate reduction of $50 \%$ for accident-free experience during a period of at least six years is granted by most insurers in Germany. On the other hand few insurance companies have a system of surcharged premiums applied in the form of penalties for an adverse experience record.

The analyses by Mehring do not provide new facts but the paper sets out a clear outline of all the important problems involved in this branch and shows how they can be tackled. The foreign reader will find an excellent survey of the standard private passenger classification rating systems applied in Germany and the novice can gain knowledge without being scared off by complicated mathematical formulae from the very beginning.

Der optimale Bonus, by MAX GüRTLER, Zeitschrift für die gesamte Versicherungswissenschaft, Berlin I 962.

In Germany and Switzerland a very simple classification plan is in use as a standard rating procedure in automobile insurance. The characteristics of the plan are: kind of vehicle (private passenger cars, taxi cabs, trucks tractors) and horsepower. To provide for a rate differential between the careful and the accident-prone driver, a credit is granted on renewal if the insurance has not been guiltily involved in an accident during a certain period. This credit, called bonus, is determined according to a scale which 